\title{
Vladimir Lamansky in Saint Petersburg University
}

\author{
A. V.Malinov, V.A.Kupriyanov
}

For citation: Malinov A.V., Kupriyanov V.A. Vladimir Lamansky in Saint Petersburg University. Vestnik of Saint Petersburg University. History, 2019, vol. 64, issue 1, pp. 211-221. https://doi. org/10.21638/11701/spbu02.2019.112

On the basis of the archival sources and memoirs of the contemporaries, the authors of the article reconstruct the university career of an outstanding Russian Slavic scholar V.I.Lamansky (1833-1914): from the period when he served as an officer in the administration of St. Petersburg Governorate to the time when he made a decision to resign from the university in protest against the government's actions during the 1899 student unrest. It is noted that the foundations of Lamansky's scholarly methodology was formed by Slavophile philosophy, since we can consider Lamansky the representative of the movement of so called academic Slavophilism. Lamansky' orientation towards philosophical approach with regard to Slavic history and culture enabled him to become a founder of an independent historiographical school, with which a number of renowned Russian scholars can be associated. The authors underline that Lamansky realized himself more as a political thinker and philosopher of history than a researcher; however, this fact did not prevent him from contributing to Russian Slavic studies as an independent discipline with its own subject and method. Exploring Lamansky's correspondence, the authors analyze Lamansky's perception of 1884 University regulations and 1899 student unrest. It enables to demonstrate the specificity of Lamansky's political views and some features of his personality. Therefore, contrary to the accepted viewpoint, prevalent in historiography since the Soviet period, according to which Lamansky was inclined to political conservatism and reactionary movement, we can argue that Lamansky's political position was of liberal nature.

Keywords: Lamansky, history of the Slavic studies, Saint Petersburg University, academic career, 1899 student unrest, philosophy of history, soft power.

\section{Владимир Ламанский в Санкт-Петербургском университете}

\section{А. В. Малинов, В.А.Куприянов}

Для цитирования: Malinov A. V., Kupriyanov V. A. Vladimir Lamansky in Saint Petersburg University // Вестник Санкт-Петербургского университета. История. 2019. Т. 64. Вып. 1. С. 211-221. https:// doi.org/10.21638/11701/spbu02.2019.112

Алексей Валерьевич Малинов - д-р филос. наук, проф., Санкт-Петербургский государственный университет, Российская Федерация, 199034, Санкт-Петербург, Университетская наб., 7-9; a.malinov@spbu.ru

Alexey V. Malinov - Doctor in Philosophy, Professor, St. Petersburg State University, 7-9, Universitetskaya nab., St. Petersburg, 199034, Russian Federation; a.malinov@spbu.ru

Виктор Александрович Куприянов - канд. филос. наук, науч. сотр., Санкт-Петербургский филиал Института истории естествознания и техники им. С.И. Вавилова Российской академии наук, Российская Федерация, 199034, Санкт-Петербург, Университетская набережная, 5; nonignarus-artis@mail.ru

Victor A. Kupriyanov - PhD in Philosophy, Research Associate, St. Petersburg branch of S. I. Vavilov Institute for the History of Science and Technology of the Russian Academy of Sciences; 5, Universitetskaya nab., St. Petersburg, 199034, Russian Federation; nonignarus-artis@mail.ru

(c) Санкт-Петербургский государственный университет, 2019 
В статье на основе архивных источников и воспоминаний современников реконструируется университетская карьера известного русского слависта В. И. Ламанского (18331914). Хотя научное творчество В.И. Ламанского уже неоднократно становилось предметом историко-научных исследований, деятельность выдающегося русского слависта в университете начиная с периода его обучения в университете в 1850-1854 гг. до сих пор не освещена. В статье показаны основные вехи научной карьеры В.И. Ламанского с первых лет работы в Санкт-Петербургском губернском правлении вплоть до решения покинуть университет в связи с протестом против действий правительства в ходе студенческих волнений 1899 г. Указывается, что основу научной методологии Ламанского составила философия славянофильства, в силу чего ученого можно отнести к числу представителей так называемого академического славянофильства. Ориентация Ламанского на философский подход к освещению славянской истории и культуры позволила ему стать основателем самостоятельной школы славяноведения, к которой можно отнести ряд выдающихся русских историков и филологов (Ф.И.Успенский, Ф.Ф.Зигель, К.Я.Грот, Т.Д.Флоринский, Н.В.Ястребов и др.). Подчеркивается, что Ламанский считал себя в большей степени политическим мыслителем и философом истории, что, однако, не помешало ему внести существенный вклад в становление российского славяноведения как самостоятельной научной дисциплины. На основе переписки ученого продемонстрировано восприятие Ламанским принятия Университетского устава 1884 г. и его поведение в ходе студенческих волнений 1899 г. Обращение к аналитике реакции ученого на указанные события позволяет показать особенности политических взглядов Ламанского, а также свойства его характера. В связи с этим вопреки распространенной еще с советских времен точке зрения, согласно которой Ламанский принадлежал по своим политическим взглядам к консервативному и реакционному направлению, можно прийти к выводу о либеральном характере политических взглядов ученого.

Ключевые слова: Ламанский, история славистики, Санкт-Петербургский университет, академическая карьера, славянофильство, студенческие волнения 1899 г., философия истории, «мягкая сила».

Vladimir Ivanovich Lamansky (1833-1914) who is usually considered to be one of the most outstanding Slavic scholars had been connected with St. Petersburg University for more than half a century ${ }^{1}$. His university activity can be divided into two periods: his student years (1850-1854) and his teaching work which spanned several decades from 1865 to the last years of his life. Being a first-year student, Lamansky was attracted by I.I.Sreznevsky's lectures which motivated him to choose Slavic studies as his scholarly interest. In those years, Lamansky was acquainted with the Slavophile doctrine which had so much influence on him that he over time became a distinguished representative of so called academic Slavophilism. Having graduated from university with a silver medal for his master's thesis and being highly disappointed with his final exams, Lamansky made a decision to look for the service outside University. Lamansky's dream to travel around Russia and Slavic countries was also not realized. Since he was extremely interested in academic research, he strived for such a position which would give him an opportunity to do so. At first he worked without salary in the administration of St. Petersburg Governorate from 20 January to 29 October 1855 , and then he was employed without salary by the Public Library for the position of an officer. The service without salary gave him an opportunity to gain the lowest rank for the tenure.

${ }^{1}$ Arzhakova L.M. Slavistika v Sankt-Peterburgskom universitete // Studia Slavica et Balcanica Petropolitana. 2017. Vol.22, no. 2. P. 172-184. 
In Library, Lamansky worked in the department «Rossica» ${ }^{2}$, which enabled him to continue his research. He wrote: "My service in the department of foreign authors' publications about Russia in the Public Library gave me an opportunity to become more acquainted with the views of the Western Europeans on Russia, its past, present and future"3. However, because of the conflict with Baron M.A.Korf (the head of the Library) he was compelled to resign. The State archive of the Foreign Affairs Ministry became his next place of employment; Lamansky worked there as a senior archivist from 1858 to 1862.

In 1858, Lamansky passed his Master's exams, and in the next year he had his large study "Concerning the Slavs in Middle Asia, Africa and Spain" published. Supplemented with the "Historical remarks to the work "Concerning the Slavs in Middle Asia, Africa and Spain", it was a voluminous book in 600 pages. The Imperial Academy of Sciences awarded half of Demidov Prize to Lamansky for this work, which was defended as Master's thesis in St. Petersburg University on 31 January 1860.

The successfully defended thesis and scientific award not only developed the self-esteem of the young scholar, but also offered him an opportunity of a scholarly career. In April 1862, Lamansky was enrolled at the Ministry of National Education. On the basis of the surviving correspondence, we can conclude that new minister, A.V.Golovin, helped Lamansky to realize his long-held dream - a trip to the Slavic countries. This journey, which was the longest in Lamansky's academic biography, lasted for nearly two and a half years. Lamansky left St. Petersburg on 5 May 1862 and returned on 1 October 1864. This trip appeared to be one of the most important events in Lamansky's biography since his studies in the Slavs previously had only been speculative and theoretical and had had the spirit of romantic Slavophilism.

Lamansky decided to use the materials gathered during the travel for his doctoral thesis. Back in St.-Petersburg, he wrote to I. S. Aksakov in the letter dated by 9 December 1864: "At the moment, I'm writing my doctoral thesis. I have chosen the Dušan's Code as a topic of my paper. I might move to Odessa"4. The service in the Ministry of National Education gave an opportunity to move on to the university. At the time, Lamansky did not envisage himself beyond science. The Imperial Novorossiya University was established in Odessa on the basis of the Richelieu lyceum in May 1865. I. I. Sreznevsky recommended that his disciple should be appointed as a professor (probably, as early as 1863$)^{5}$. On 11 January 1865 Lamansky wrote to I. S. Aksakov: "They are offering me to move to Odessa on unfavourable conditions, moreover, having to leave my Mom hurts. The local university almost tells me that they don't need me and offer me to be a Privatdozent, that is, a simple teacher without voice and salary. In a nutshell, they offer me something which I rejected almost five years ago" 6 . Lamansky became a professor of Novorossiya University

2 Saprikina O. V. Akademik V. I. Lamanskij (1833-1914): nauchnoe nasledie i obshchestvennaia deyatel'nost': avtoref. dis. ... kand. ist. nauk. M., 2004.

${ }^{3}$ Lamansky V.I. Rech', proiznesennaia v S.-Peterburgskom universitete 31 ianvaria 1860 g. pri publichnoi zashchite dissertatsii na stepen' magistra: "O Slavianakh v Maloi Azii, Afrike i v Ispanii” // Russkaia beseda. 1860. Book. 19, no. 1. P. 139 .

4 Sankt-Peterburgskiy filial arkhiva RAN. F. 35. Op. 1. Ed khr. 1. L. 64.

${ }_{5}$ Markevich A.I. Dvadtsatipyatiletiie Imperatorskogo Novorossiiskogo universiteta. Istoricheskaia zapiska i akademicheskiie spiski. Odessa, 1890. P. 114.

${ }^{6}$ Sankt-Peterburgskiy filial arkhiva RAN. F.35. Op. 1. Ed khr. 1. L. 64-65. 
on 17 March 1883 as its honorary member. The same year he was elected an honorary member of St. Vladimir University in Kiev ${ }^{7}$.

On 26 April 1865 Lamansky was appointed to the department of Slavic philology as a Privatdozent. Lamansky's introductory lecture was published in Moscow in "Den", the newspaper edited by I.S. Aksakov (1865, no. 50-52), in the Viennese journal "Zolotaya gramota" (1865, no. 23; 1866, no. 25), and as a separate brochure as well. According to the current tradition, a teacher had to explicate his views on the subject in the public introductory lecture. Lamansky explicitly indicated his Slavophile views and connected the success of the Russian Slavic studies with the activity of the Slavophile circle. On the whole, the subjects Lamansky taught were concerned with history and literature of the Slavic nations. Nevertheless, his first lecture was devoted to the philosophical-historical issues. In the spirit of A. S. Khomiakov, he acknowledged the fundamental significance of faith for the history and culture of nations.

In the subsequent years, Lamansky voiced his philosophical views when he started his courses. It enabled him to outline the basic philosophical positions which he used for interpretation of historical material. Lamansky rarely addressed Slavic philology; as a rule, he lectured about history of the Slavic nations. I. V. Yagich, invited to the department of Slavic philology on the initiative of Lamansky, testified that "our students are little acquainted with philology: so far, under Lamansky's influence they have only been studying history"8. During his university career, Lamansky taught a wide range of courses on Slavic history, languages and literature.

The preparation for the lectures took him much time. Most of the works published by Lamansky were connected with his teaching activity in the university, and his studies in Slavic nations were reflected in his lectures. He constantly updated the content of his lectures and acquainted students with the recent advances in the Slavic studies. In the letter to I.S.Aksakov he confessed: "You say that you haven't heard from me. The thing is that my lectures and preparation for them take me too much time. I read about Czech and Poland in the $15^{\text {th }}-16^{\text {th }}$ centuries. I have to read any sort of the old stuff. Moreover, I'm busy in our Uni[versity] Histor[ical] Philol[ogical] Soc[iety], where I'm a chairman and trying to make its periodical edition. I'm trying to attract more people, especially young. Once things get better, it will bring about benefits not only in scientific and literary spheres, but also in the public one"9. The only sources of his income were teaching and literary work (from November 1872 Lamansky also held the chair of Russian and Church Slavonic languages, and chair of history of Russian literature in Saint Petersburg Theological Academy).

Industriousness was not only the feature of Lamansky's personality, but also condition for his survival. Financial difficulties, which he used to experience, made the tone of his correspondence pessimistic. His scholarly research rarely generated income, while journalism compelled him to be distracted by fleeting political life. Realizing contradictions between academic work and political journalism, he undoubtedly chose science. His account of the death of A. F. Hilferding given to I.S. Aksakov can serve as a proof for this statement ${ }^{10}$.

\footnotetext{
7 Otdel rukopisei Rossiiskoi natsional'noi biblioteki (future - OR PNB). F. 340. K. 3. No. 615. L. 59.

8 Pis'ma I. V. Yagicha k russkim uchenym. 1865-1886. M; L., 1963. P. 203.

9 Sankt-Peterburgskiy filial arkhiva RAN. F. 35. Op. 1. Ed khr. 1. L. 163.

10 Ibid. L. 86.
} 
Lamansky was quite critical about his university colleagues. In the undated letter to his disciple A.S. Budilovich, he made an extremely negative assessment of both his colleagues and university science as a whole: "Nevertheless, we are doing very poorly indeed. Aksakov and Katkov do not have any talented colleagues and disciples, and they both are not young yet. The "Novoe vremya" is actually vain and vulgar. Everything else is nasty and rotten in Moscow and Petersburg. Both our and Moscow university are not the worst in Russia, moreover, they might be the best. But what do they have? Few really clever and distinguished people among plenty of self-satisfied boneheads and, what's more, corny and mindless windbag-liberals. Look at the modern Russian historiography. Nikitsky is the most efficient and serious scholar in this field. Ilovaysky disgraces himself by his works on Normans, Bulgarians and Huns, without realizing it. Bestuzhev hasn't done anything in a long time and he is not able to do something. Zamyslovsky is a good person, he is diligent but, in my opinion, too narrow-minded. Klyuchevsky is too busy. Moscow turned to Pypin instead of Buslaev, but once he rejected, they turned to Alexey Veselovsky. It is a frightful decay indeed. And Nil Popov is a fool and narrow-minded, moreover, he is not a scholar at all. We don't have any young productive people studying either Russian history or Russian literature"11. We can rightly doubt the objectivity of the Lamansky's account. Lamansky expressed his inner vision of the processes which took place in Russian academic circles.

Scholarly research enabled Lamansky to overcome the pessimistic mood which the university science put him in . Research was a way of moral survival. When he was back to the university, he started considering the doctoral thesis. In the beginning, Lamansky planned to study history of the Slavic common law, in particular, the "Dušan's Code". However, he shortly rejected this project.

His doctoral thesis extended his master's work; but it was not only supplemented with the new facts but also was based on a new conception of clear philosophical character. Analyzing the foreigners' opinions about the Slavs and Russia, he tried to propose historiosophical and political interpretation of the historical facts. Lamansky's work was aimed at explication of the European ideology reflected in the real historical events. He firstly focused on the views of the German scholars, as Germans had had the closest ties with the Slavs for a millennium. As a result, German scholarship largely shaped the European views on the Eastern Europe. He had already relied on this presumption when he worked on his master's thesis. He believed that German scholarship was dependent on politics and was determined by German expansionism. During the defense of the thesis, Lamansky claimed: "It seems clear that existential interests force Germans to absorb Slavic nations, they strive to germanize Western and Southern Slavs"12. German scholarship aims to justify these interests. It seeks to search for the weaknesses of the Slavs in order to drive them apart. The final aim is to assimilate and to enslave them. Therefore, Slavs have to understand the ideological basis of the German politics which can be found in German scholarship. In contrast to the military, German science plays the role of soft power, trying to show the assimilation as inevitable and favorable process for them. Having adopted the idea of the supremacy of the Germans, Slavs begin to strive for assimilation, as they believe that this is the only way for them to become "Europeans". Contrary to this ideology, Lamansky tried to demonstrate what Germans and Europeans actually thought about the

${ }^{11}$ Ibid. Ed khr. 14. L.4-5.

12 Lamansky V.I. Rech', proiznesennaia v S.-Peterburgskom universitete 31 ianvaria 1860 g. P. 143. 
Slavs. This was the research task of his doctoral thesis. Therefore, he called it a study in "some poorly known, or incorrectly considered issues of political and cultural history of Eastern Europe, or Greek-Slavic World in both the Middle ages and the Modern time"13.

In order to gather the necessary materials and finish the thesis, Lamansky made an overseas trip. He spent most of his time working in the Venetian archives and libraries. This trip can be considered to have been the most productive for him. He not only nearly completed his thesis, but also drew substantial archival material which he partly published in a separate volume called "Secrets d'État de Venise. Documents, extraits, notices et études servant à éclaircir les rapports de la Seigneurie avec les grecs, les slaves et la Porte Ottomane à la fin du XV-e et au XVI-e siècle" (SPb., 1884). In his correspondence, he confessed that he looked upon this work as his main scholarly achievement.

The abridged version of the foreword to the "Secrets d'État de Venise" was published in the "Rus" 14 , the newspaper edited by I.S. Aksakov. The second part of the foreword was published in the French language in Florence in the "Revue Internationale" (1884. Mars. Tome I. S. 851-866) under the title "Le Panslavisme par Vladimir Lamansky". This title was proposed by the editor of the journal A. de Gubernatis. It can be regarded as one of the main Lamansky's philosophical texts since his Slavophile views were fully presented there.

Lamansky spent more than a year abroad: having left St.-Petersburg in spring 1868, he returned to Russia in July 1869; he visited Prague, Zagreb, Ljubljana, Udine and Milan, and then spent about a year in Venice. At the same time, he published a series of articles called "An unsolved issue"15 in the "Journal of the Ministry of National Education"; these articles were highly appreciated by the Slavic scholars. In the articles under consideration, Lamansky formulated his views on the origins of Old Church Slavonic and Russian languages. His central idea was concerned with the justification of making Russian the new international Slavic language serving as a means of diplomatic and cultural communication. He also raised the problem of Bulgarian language and literature of the $16^{\text {th }}-18^{\text {th }}$ centuries. I. I. Sreznevsky proposed that these articles be submitted to the Council of the historical-philological faculty as doctorate thesis. On return from Venice, Lamasky's doctoral thesis called "Concerning the historical studies in the Greek-Slavic World in Europe" was nearly finished. In 1870, he undertook publication in the Slavophile journal "Zarya"16, and then, in 1871, the thesis was published in a separate volume ${ }^{17}$. The thesis was successfully defended on 21 March 1871, and the Council of St. Petersburg University granted Lamansky "the degree of the Doctor in Slavic philology"18.

The ideas in Lamansky's thesis were similar to those in N. Y. Danilevsky's work "Russia and Europe: A Look at the Cultural and Political Relations of the Slavic World to the Romano-German World" (separate edition in 1871), but they did not receive any response P.I.

${ }^{13}$ Lamansky V.I. Ob istoricheskom izuchenii greko-slavianskogo mira v Evrope. St. Petersburg, 1871.

${ }^{14}$ Lamansky V.I. Secretes d'Etat de Venise et rapports de la République avec les Grecs, les Slaves et les Turcs au XVI siècle. Documents, extraits, notices et etudes. St.-Pétersbourg. 1884 (tom v 65 listov uboristoi pechati) 8) // Rus'. 1883. 15 November. No. 22. P.23-41.

${ }^{15}$ Lamansky V.I. Neporeshennyi vopros // Zhurnal ministerstva narodnogo prosveshcheniia. 1869. No. 1. P. 122-163; No. 6. P.349-378; No. 7. P. 84-378.

${ }^{16}$ Lamansky V.I. Ob istoricheskom izuchenii greko-slavianskogo mira v Evrope // Zaria. 1870. No. 1. P. 8-67; No. 2. P. 1-65; No. 5. P. 1-77; No. 12. P. 44-161.

17 Lamansky V.I. Ob istoricheskom izuchenii greko-slavianskogo mira v Evrope. St. Petersburg, 1871.

18 Protokoly zasedanii Soveta St. Peterburgskogo universiteta za vtoruiu polovinu 1870-1871 akademicheskogo goda s prilozheniiami. No. 4. SPb., 1871. P. 35. 
in the Russian society and press. No review of the book was published, and over time it had been overshadowed by the well-known Danilevsky's work. Among the responses to Lamansky's text, one can only mention an overview of the history of Slavic studies (before 1872) published in the Kiev the "Slavyanskiy ezhegodnik" (Slavic yearbook). There was only one passage devoted to Lamansky ${ }^{19}$.

We can conclude that the 1860s-1870s were the heyday of Lamansky's teaching and scholarly career. In those years, he formulated the essential tenets of his philosophical doctrine and won recognition of the colleagues, having become one of the most eminent Slavic scholars all over Europe. He also made a good university career during that period. After he had defended his doctoral thesis, he was elected Professor extraordinarius of the Slavic philology chair (38 votes to 3 ). Moreover, the University Council requested the curator of the Educational district to pay Lamansky the professor's salary. On 27 January 1873 historical-philological faculty elected Lamansky Professor ordinarius, and on 5 January of the same year there was a ballot in the university council. Lamansky was elected Professor ordinarius of the Slavic philology chair by 33 votes to $3^{20}$.

The situation changed when the Ministry undertook the revision of the 1863 "The University Charter". Lamansky again considered moving from St.Petersburg. In letters to I.S. Aksakov, he expressed his opinion about the initiators (M. N. Katkov and N. A.Liubimov) and the very reform ${ }^{21}$.

By the time the preparation to the imposing of the regulations restricting the university autonomy was well under way, Lamansky had been elected a dean of the historical-philological faculty and on 11 March 1883 this position was approved by the minister of the National education. According to the 1884 "The University Charter", the deans were appointed by the minister, therefore, over time, the minister reappointed Lamansky. Nevertheless, as Lamansky did not want to be an instrument of the governmental policy infringing the academic freedom, in the autumn of 1885 he submitted his resignation ${ }^{22}$. His letters to the colleagues are full of regret about the situation in university. For example, we can cite his letter to I. S. Aksakov: "On the one hand, the current reform is inspired by the merely repressive tendency to eradicate nihilism, by the very repressive means, on the other hand, it is provoked by the poor westernization movement of the 1840s which imagined that there had never been anybody higher than Granovsky, Redkin, Katkov, Leontev and Liubimov in the university" ${ }^{23}$. As much as it was possible, Lamansky resisted these restrictions imposed by the new governmental rules. In the subsequent years, being a senior member of the faculty council, he rarely acted as a dean, although it was required by the article 26 of the 1884 "University Charter".

M.I. Vladislavlev who succeeded Lamansky in the position of the dean of the Historical-Philological faculty became an obedient agent in the governmental policy. Following the moral evaluations given by the contemporaries, Russian historiography created a negative image of M. I. Vladislavlev. E. A. Rostovtsev successfully attempted to revise

19 Uspekhi slavianovedeniia v Rossii do 1872 goda. Po A. A. Maikovu, P. A. Lavrovskomu i A. A. Kotliarevskomu // Slavianskiy ezhegodnik. Kalendar' na 1876 god. Kiev, 1876. P. 46.

20 Protokoly zasedanii Soveta Imperatorskogo S.-Peterburgskogo universiteta za vtoruiu polovinu 1873-1874 akademicheskogo goda s prilozheniiami. No. 8. SPb., 1874. P. 44.

21 V.I. Lamansky's letters to I. S. Aksakov // F. 35. Op. 1. Ed khr. 1. L. 174-175, 187.

22 Protokoly zasedanii Soveta Imperatorskogo Sankt-Peterburgskogo universiteta za pervuiu polovinu 1885-1886 akademicheskogo goda. No. 33. SPb., 1886. P. 43.

${ }^{23}$ V.I. Lamansky's letters to I. S. Aksakov. L. 182. 
it and suggested rejecting so unambiguously negative perception of M. I. Vladislavlev: "We should say that in spite of the total distrust and boycott from the side of the liberal professors, Vladislavlev was quite active in reforming academic process in accordance with the requirements of science and corporation" ${ }^{24}$. In spite of the ministerial dictatorship, M.I. Vladislavlev managed to extend the philosophy courses ${ }^{25}$. Lamansky was not M.I. Vladislavlev's friend. However, it is impossible to say that they had only professional ties. For instance, it is known that V.I. Vladislavlev recommended Lamansky a nurse for his children. Subsequently, Lamansky corresponded with M. I. Vladislavlev's son Vladimir Michailovich Vladislavlev (1868-1943). Nevertheless, Lamansky could not agree with the infringement of the academic freedom and restriction of the university teaching which M. I. Vladislavlev had to realize being a rector of the University and a dean of the faculty ${ }^{26}$.

It is to be noted that Lamansky considered administrative functions a burden which distracted him from scholarly work. He thought that administrative career was not worth the sacrifice on the part of real men of science; he found counterexamples surprising ${ }^{27}$.

Most of the rules of the 1884 Charter had gradually been revised and university life restored the autonomy. University professors demonstratively expressed discontent with the ministry, the opposition strengthened, and a considerable part of the professors turned to liberalism. For instance, at Lamansky's suggestion, the Council of St.-Petersburg University made a decision to read the scientific dossiers before appointing candidates to professorial posts (professors had to be appointed by the Ministry of the National education). We can see the expectation of the social changes in Lamansky's correspondence, although the prevailing mood can be characterized as skepticism and doubt ${ }^{28}$.

The sense of professional uselessness was added to the university squabbles. The point is not that Lamansky was not probably a successful teacher. He did not strive for popularity. Apart from the university teaching, he tried to apply his knowledge about history, everyday life and modern state of the Slavic nations to real practice. He was not only a theorist. He realized himself as a philosopher and a political thinker; he wrote articles concerning the current political issues and contributed to assisting the Balkan Slavs. His knowledge required a practical realization. The University was too tight for him. It is no coincidence that Lamansky put such extraordinary effort into working in Saint-Petersburg Slavic charitable society, the Ethnographical department of the Imperial geographical society, the Literary foundation. He was at the forefront and among the founders of the Slavic committee (later Slavic charitable society) and Literary foundation; he was an organizer of the 1867 Slavic congress, and the author of the early project of St.-Petersburg ethnographic museum. Being an editor, he tried to influence the society and deliver his views on Slavs to the people. He was an editor of the "Izvestiya Sankt-Peterburgskogo slavyanskogo blagotvoritel'nogo obshhestva" (1887-1888); he published and edited Russian pre-revolutionary journal "Zhivaya starina" (1890-1912) ${ }^{29}$. Lamansky not only worked for free, but

${ }^{24}$ Rostovtsev E. A. Stolichnyi universitet Rossiyskoi imperii: uchenoie sosloviie, obshchestvo i vlast' (vtoraia polovina XIX - nachalo XX v.). M., 2017. P. 460.

25 Rostovtsev E. A., Sidorchuk I. V. Kafedra filosofii Peterburgskogo universiteta (1819-1917): Kollektivnyi portret // Filosofskiie nauki. 2016. No. 3. P.137-138.

26 OR PNB. F. 340. K. 2. No. 33. L. 59.

27 Rostovtsev E. A. Stolichnyi universitet Rossiiskoi imperii... P. 465.

28 Sankt-Peterburgskiy filial arkhiva RAN. F. 35. Op. 1. Ed khr. 3. L. 9.

29 Savickii A. Chto znachit byt' slavianinom v sovremennom mire? K probleme slavianskoi identichnosti. Filosofskii polilog // Zhurnal mezhdunarodnogo centra izucheniia russkoi filosofii. 2017. No. 2. P.7-16. 
also paid his own money for publishing the journal in the early period of its existence. He probably perceived the invitation to lecture in the General staff academy as an opportunity to voice his views to those on whom the political future of Russia and Slavdom depended. In the General staff academy, he had taught for ten years (1890-1900). These were the years when he finished working on his main geopolitical treatise called "Three worlds of Asian-European continent" $(1892)^{30}$.

In his letters, Lamansky reflected on political events and shared his ideas concerning European affairs, history and perspectives with his friends. In one of his epistles to I. S. Aksakov dated from 10 February 1882, he pointed out to the gap between political power and intellectual elite. The scientists with their knowledge were held back by "the upper spheres". We cannot find claims of an intellectual to power in Lamansky's lamentations, but we see an acknowledgement of the social gap and the social disease making scientists weak and power blind: "Even princes try to become acquainted with professors, scientists and writers in Austria. In contrast, we are separated from the ruling spheres by something like the Great Chinese Wall. You can laugh that sitting in an office on Protopopovskaya street (that is, on Vvedenskaya), we don't even know life. Where there is no thought exchange and actual communication between the people from various spheres, there is no education and sound national development"31.

In 1890, having served twenty-five years in university, Lamansky became an honorable professor. 1899 was the last year of his academic career. In February 1899, there was student unrest in the universities. The protests were extremely strengthened by the tactless conduct of rector V. I. Sergeevich who called students to desist from disturbing public order. Professors (among whom there was a large number of liberals) demanded investigation into the police conduct. N.I. Kareev wrote: "The private meetings of the professors and other related persons were started. Sergeevich acted unacceptably: he was actually torturing the members of the University council who suggested something which he disliked $\langle\ldots\rangle$ when old Lamansky suddenly walked to the middle of the chamber and addressed him with approximately such a speech: "Vasily Ivanovich! We appeal to you with a friendly request. Please resign from the rectorship; students dislike you, don't destroy the university. We will be so grateful to you". Then he turned around as if he was seeking support from his colleagues, but nobody stirred. I was ashamed and rising from my seat, I loudly declared: "Vladimir Ivanovich, I agree with you". I think that this act was among the reasons why I was dismissed from the university. Sergeevich replied that he had been appointed to his post in accordance with the "will of the Tsar" and, therefore, it was not us who could dismiss him"32. Not only N.I. Kareev was dismissed from the university, buy also privatdozents M. I. Sveshnikov, S. A. Vengerov, I. M. Grevs, N. M. Knipovich and A. A. Isaev. Professor S. F. Oldenburg and privatdozent Y. I. Smirnov resigned in protest against the decision of the ministry. In these circumstances, Lamansky also decided to leave university.

In 1900, Lamansky was elected a member of the Imperial Academy of Sciences. The unfinished opus "Slavic life of Saint Cyril as a religious and epic work and as a historical

30 Prokudin B. A. Istoriosofskie i geopoliticheskie idei V. I. Lamanskogo // Vestnik of Moscow University. Ser. 12. Political Science. 2013. No. 2. P.117-127; Robinson M.A. V.I.Lamanskii i ego istoriosofskii traktat "Tri mira Aziisko-evropeiskogo materika” // Slavianskii al’manakh. 1996. P.90-106.

31 Sankt-Peterburgskii filial arkhiva RAN. F.35. Op. 1. Ed khr. 1. L. 168.

32 Kareiev N. I. Prozhitoie i perezhitoie. L., 1990. P.205-206. 
source" was Lamansky's last scholarly contribution. It was published in the "Journal of the Ministry of National Education" in 1903-1904. Subsequently, it was published as a separate edition after his death ${ }^{33}$. Since he did not have an opportunity to pursue his academic interests, he made a decision to sell his library to the university.

However, we can conclude that Lamansky's works did not have much influence on scholarship. He did not leave any considerable texts devoted to the issues of the Slavic studies. His works can be characterized as general historiosophical considerations proposing overall sketches of Slavic history. As a rule, he did not deal with the historical details and scrupulous analysis of the historical facts. His contribution to scholarship concerns methodology: he managed to elaborate his own view on Slavic studies and general interpretation of the Slavdom. His scientific methodology was based on Slavophilism, and it can therefore be called applied Slavophilism ${ }^{34}$.

This was not only the most important Lamansky's contribution. His specific view and non-typical approach to history and philology enabled him to create his own school with which a range of outstanding scholars can be associated. We can mention such scholars as Y.S. Annenkov, V.E. Regel, P. A. Syrku, I.S. Palmov, F. I. Uspensky, F. F. Zigel, A. S. Budilovich, R. F. Brandt, M. I. Sokolov, K. Y. Grot, T. D. Florinsky, N. V. Yastrebov, A. L. Pogodin and G.M.Knyazev ${ }^{35}$. An outstanding geographer V.P. Semyonov-Tyan-Shansky called himself a Lamansky's disciple (V.P. Semyonov-Tyan-Shansky was Lamansky's son-in-law).

The above mentioned fact is not surprising as broad philosophical worldview is needed to create an academic school. Lamansky perceived himself more as a political thinker and a philosopher than a narrow historian and philologist. Mere historical and philological studies could hardly serve as a means for creating a new school as theoretical and ideological presuppositions to discover new perspectives are required to attract other scientists. This is what is usually called a scholarly program, and Lamansky was among those who had managed to formulate productive and working theoretical frame for concrete empirical researches carried out by his followers and disciples.

Lamansky not only called for philosophical understanding of the history of the Slavs, but also showed how it was possible in practice. He rarely finished his works; his literary legacy includes a considerable number of articles which can be attributed to political journalism based on Slavophile philosophy. He tried to disseminate political ideas by his articles. He considered science a basis for political action and worldview, and strived to influence political situation in Russia and Europe. But he essentially believed that any change in practice could only be implemented by means of reformation of thinking. Therefore, he aimed at changing worldview. In his opinion, the right understanding of history and culture served as a foundation for political development. This is what is relevant to modern ideology of so called soft power: change of political situation by means of change of political discourse. Lamansky's aim was to shape political and ideological discourse. What is important in such a conception of soft power is the fact that, according to Lamansky, such political discourse could be formed on the basis of scholarship science. Therefore,

${ }^{33}$ Lamansky V.I. Slavianskoie zhitiie Sv. Kirilla kak religiozno-epicheskoie proizvedeniie i kak istoricheskii istochnik. Kriticheskiie zametki. St. Petersburg, 1915.

${ }^{34}$ Malinov A. V. Politicheskoie slavianovedeniie V. I. Lamanskogo // Klio. 2016. No. 8 (116). P. 67-68.

35 Lapteva M. P.: 1) Istoriia slavianovedeniia v Rossii v XIX v. M., 2005. P. 378-431; 2) Universitetskoe slavianovedenie v Rossii za pervoe stoletie ego sushchestvovaniia (1835-1935) // Slavianskii al'manakh. 2010. P. 94-110. 
scientific scholarly cognition shaped by the right philosophical presumptions served as a condition for political ideology determining political reality. Such approach to science which inevitably calls on complex philosophical generalizations determined the fact that Lamansky's methodology and worldview were so appealing to young scholars, some of whom tried to continue Lamansky's integration of science, politics and philosophy.

Lamansky's Slavophilism manifested itself in his historiosophical interpretations and philosophical generalizations. His approach can be called more political and philosophical than philological ${ }^{36}$. It is no accident that the importance of Lamansky as a Slavic scholar had gradually been declining, while his importance as a political thinker and a Slavophile philosopher grew along with the expansion of historical and philosophical studies in Russia. According to A. A. Shakhmatov, Lamansky was not an abstract thinker or a distanced moralist: "Scholarly interests were close to him, but, above all, he was a passionate patriot" 37 .

\section{References}

Arzhakova L.M. Slavistika v Sankt-Peterburgskom universitete. Studia Slavica et Balcanica Petropolitana, 2017, vol. 22, no. 2, pp. 172-184. (In Russian)

Ishboldin B. The Eurasian Movement. The Russian Review, vol. 5, no. 2, 1946, pp. 64-73.

Kupriyanov V. A., Malinov A. V. "Ya sluzhu narodnosti..." (k publikatsii “Istoricheskikh pisem ob otnosheniiakh russkogo naroda k ego soplemennikam" V. I. Lamanskogo). Studia Slavica et Balcanica Petropolitana, 2016, vol. 20, no. 2, pp. 89-111. (In Russian)

Lapteva L. P. Istoriia slavianovedeniia $v$ Rossii v XIX v. Moscow, Indrik, 2005, 840 p. (In Russian)

Lapteva L. P. Universitetskoe slavianovedenie v Rossii za pervoe stoletie ego sushchestvovaniia (1835-1935). Slavianskii al'manakh, 2010, pp. 94-110. (In Russian)

Malinov A. V. Politicheskoe slavianovedenie V. I. Lamanskogo. Klio, 2016, no. 8 (116), pp. 62-71. (In Russian)

Prokudin B. A. Istoriosofskie i geopoliticheskie idei V. I. Lamanskogo. Vestnik of Moscow University. Ser. 12. Political Science, 2013, no. 2, pp 117-127. (In Russian)

Robinson M.A.V.I.Lamanskii i ego istoriosofskii traktat "Tri mira Aziisko-evropeiskogo materika". Slavianskii al'manakh, 1996, pp. 90-106. (In Russian)

Rostovtsev E. A. Stolichnyi universitet Rossiiskoi imperii: uchenoie sosloviie, obshchestvo i vlast' (vtoraia polovina XIX - nachalo XX v.). Moscow, ROSSPEN, 2017, 903 p. (In Russian)

Rostovtsev E. A., Sidorchuk I.V.Kafedra filosofii Peterburgskogo universiteta (1819-1917): Kollektivnii portret. Filosofskiie nauki, 2016, no 3, pp. 135-147. (In Russian)

Savickij A. Chto znachit byt' slavianinom v sovremennom mire? K probleme slavianskoi identichnosti. Filosofskii polilog. Zhurnal mezhdunarodnogo tsentra izucheniia russkoi filosofii, 2017, no 2, pp. 7-16. (In Russian)

Saprikina O. V.Akademik V.I.Lamanskii (1833-1914): nauchnoe nasledie i obshchestvennaia deiatel'nost'. Avtoref. dis. ... kand. ist. nauk. Moscow, 2004, 292 p. (In Russian)

Received: June 18, 2018

Accepted: November 30, 2018

Статья поступила в редакцию 18 июня 2018 г.

Рекомендована в печать 30 ноября 2018 г.

${ }^{36}$ Ishboldin B. The Eurasian Movement // The Russian Review. 1956. Vol. 5, no. 2. P. 64-73; Kupriyanov V.A., Malinov A. V. "Ya sluzhu narodnosti..." (k publikacii "Istoricheskih pisem ob otnosheniyah russkogo naroda k ego soplemennikam" V.I. Lamanskogo) // Studia Slavica et Balcanica Petropolitana. 2016. Vol. 20. P. 89-111.

37 Shakhmatov A. A. Vladimir Ivanovich Lamansky. Nekrolog (Chitan v zasedanii Obshchego Sobraniya 29 noiabria 1914 g. akademikom A. A. Shakhmatovym) // Izvestiia Imperatorskoy Akademii nauk. 1914. P. 1345. 